\title{
Case Study: A Career Development Program for New Engineering Faculty
}

\author{
Edward Hensel, Ph.D. ${ }^{1}$, Risa Robinson, Ph.D. ${ }^{1}$ \\ ${ }^{1}$ Rochester Institute of Technology, Rochester, NY, USA, hensele@asme.org, rjreme@ rit.edu
}

\begin{abstract}
The career progression of new hire junior faculty is a topic of growing interest in higher education. This article presents a career development program for tenure track assistant professors aimed at improving many aspects of early career performance. The motivations for this case study are to enhance the progress of faculty members early in their career, and to evaluate whether a comprehensive career development program enhances the performance of junior faculty members in their progress towards promotion and tenure. A career development program was piloted in the Mechanical Engineering Department at the Rochester Institute of Technology. The impact was evaluated by comparing the career progress of six faculty hired after creation of the program to four faculty hired before. The career development program included elements associated with teaching, scholarship, and service. Performance data for each of these three areas was collected, in addition to a faculty self-assessment of their understanding of tenure and promotion expectations. Results of the case study indicate that the assistant professors engaged in the career development program performed at a level equal to or higher than the assistant professors not engaged in the career development program for every metric measured. A comprehensive career development program for tenure track assistant professors may contribute to improving many aspects of early career performance and improve faculty performance and satisfaction during the early years of their career.
\end{abstract}

Keywords-University Management, Engineering Faculty Development.

Digital Object Identifier

(DOI):http://dx.doi.org/10.18687/LACCEI2016.1.1.216

ISBN: 978-0-9822896-9-3

ISSN: 2414-6390

$14^{\text {th }}$ LACCEI International Multi-Conference for Engineering, Education, and Technology: "Engineering Innovations for Global Sustainability", 20-22 July 2016, San José, Costa Rica. 


\title{
Case Study: A Career Development Program for New Engineering Faculty
}

\author{
Edward Hensel, Ph.D. ${ }^{1}$, Risa Robinson, Ph.D. ${ }^{1}$ \\ ${ }^{1}$ Rochester Institute of Technology, Rochester, NY, USA, hensele@asme.org, rjreme@rit.edu
}

\begin{abstract}
The career progression of new hire junior faculty is a topic of growing interest in higher education. This article presents a career development program for tenure track assistant professors aimed at improving many aspects of early career performance. The motivations for this case study are to enhance the progress of faculty members early in their career, and to evaluate whether a comprehensive career development program enhances the performance of junior faculty members in their progress towards promotion and tenure. A career development program was piloted in the Mechanical Engineering Department at the Rochester Institute of Technology. The impact was evaluated by comparing the career progress of six faculty hired after creation of the program to four faculty hired before. The career development program included elements associated with teaching, scholarship, and service. Performance data for each of these three areas was collected, in addition to a faculty self-assessment of their understanding of tenure and promotion expectations. Results of the case study indicate that the assistant professors engaged in the career development program performed at a level equal to or higher than the assistant professors not engaged in the career development program for every metric measured. A comprehensive career development program for tenure track assistant professors may contribute to improving many aspects of early career performance and improve faculty performance and satisfaction during the early years of their career.
\end{abstract}

Keywords-University Management, Engineering Faculty Development.

\section{INTRODUCTION}

Faculty development programs have been discussed for quite some time in the literature, predominantly resulting in conference presentations and workshops. Limited work is available on pre-service faculty development programs focused on engineering faculty [1,2], while there are numerous examples of professional development programs for in-service engineering faculty [3-13]. Many in-service programs focus on specific areas of faculty development, such as improvement of student retention [11,12], improvement of teaching effectiveness $[4,7,8]$, or outcomes assessment [5]. Several faculty development programs focus on individual $[14,16]$ or small group [15,17] peer mentoring approaches. Closely related to the issue of faculty development is that of faculty performance assessment [18-21], with a particularly relevant recent article which points to the important link between measures of performance and actual improvements achieved [21]. Assessment of the effectiveness of the faculty development programs [22-30] is often qualitative. Some faculty development programs focus on issues specific to an engineering discipline [31-33], technology programs [34-36], adjunct or non-traditional faculty [37], and faculty at two-year institutions [38-39]. In contrast, the case study presented herein is intended to be broadly applicable to a wide range of engineering and technology disciplines, using quantitative data to assess both the effectiveness of the faculty development program and the performance improvements of individual faculty. This paper introduces and evaluates a multi-year inservice program that addresses all aspects of early career development and success.

\section{EXPECTATIONS FOR PROMOTION AND TENURE}

A successful Career Development Program (CDP) for new faculty begins with a clear set of expectations. While institutions have varying expectations of their junior faculty, a CDP for new faculty must be closely related to the institution's expectations. This section summarizes the expectations of tenure-track faculty members who aspire to earn tenure and promotion to the rank of rank of Associate Professor in the Mechanical Engineering (ME) Department of the Kate Gleason College of Engineering (KGCOE) at the Rochester Institute of Technology (RIT). This context is essential to illustrate the reasons for each aspect of the CDP employed to guide junior faculty through the first several years of appointment in mechanical engineering at RIT.

Faculty members are expected to demonstrate excellence in teaching and educational activities; scholarship, research, and creative activities; and professional service activities in order to earn tenure and the rank of Associate Professor in the KGCOE. As excerpted from the RIT Policy and Procedures: "... teaching is the foremost activity of the RIT faculty is deeply rooted in the traditions of the institution, and the primacy of teaching continues to be a hallmark of RIT. ... Consequently, the basic consideration, both in initial appointments and matters pertaining to salary adjustments, promotion and tenure, is the extent to which high standards of teaching can be achieved and maintained ... it is expected that the faculty member will develop excellent skills as an educator, and will develop relationships with students and colleagues outside of, as well as inside, the classroom. The faculty member should place emphasis on the quality of the educational offerings provided to the students and on the extent to which students achieve the learning outcomes of the courses taught." [40].

KGCOE teaching and educational activity guidelines articulate that faculty members are expected to have successfully taught courses at both the undergraduate and graduate level prior to being considered for tenure, and that they will have provided innovation to the curriculum. The ME department considers advising of undergraduate students as a

Digital Object Identifier (DOI): http://dx.doi.org/10.18687/LACCEI2016.1.1.216 ISBN: 978-0-9822896-9-3

ISSN: 2414-6390

14 ${ }^{\text {th }}$ LACCEI International Multi-Conference for Engineering, Education, and Technology: "Engineering Innovations for Global Sustainability”, 20-22 July 2016, San José, Costa Rica. 
significant element of each faculty member's plan of work. Accordingly, advising is included as part of the annual evaluation process, and is considered during the tenure review process in a manner consistent with the faculty member's annual work plan for teaching and educational activities.

Each faculty member is expected to develop a scholarship program that fosters interaction with students through mechanisms such as graduate student advising and undergraduate design projects, while advancing the state of the art within a specific professional discipline. Each faculty member is expected to publish the results of his or her scholarly activity in a variety of venues, such as conference proceedings, presentations, and technical journals. Faculty members are expected to support their scholarship program through external funding such that the faculty member can sustain and grow his or her scholarship program. As stated in the KGCOE Tenure Policy and Procedures, “...Faculty scholarship should support three objectives: (1) help faculty members remain current in their area of expertise, and remain energetic and excited about their field for the duration of their career, (2) have a direct and measurable positive impact on individually identifiable students, and (3) enhance the reputation of the department, the Kate Gleason College of Engineering, and the university..." [41].

Tenure-track faculty members are encouraged to be members of professional societies and serve on technical program committees in their discipline. KGCOE policy states that "... committee service should not impede the untenured faculty member's primary focus on developing skills as an excellent educator and establishing a scholarly activity program. Service as a referee for peer-reviewed journals, conference proceedings, and grant proposals to sponsoring agencies is viewed as an excellent mechanism for untenured faculty to develop professional relationships beyond the boundaries of the campus..." [40]. Community service is an excellent way to help faculty members and their families become active members of the local community, and contribute to their sense of being "at home" in the area. While not required as part of the tenure process, local community service and similar connections are encouraged and facilitated.

The CDP for new faculty addresses each of these expectations during a multi-year effort. Each activity in the CDP relates to fostering success in each area of expectation.

\section{CAREER DEVELOPMENT PROGRAM DESCRIPTION}

The CDP for new faculty in the RIT ME department extends from the date of hiring through the conclusion of the Tenure and Promotion (T\&P) process. Activities included each year are intended to help the new faculty member succeed in all expectations for T\&P.

\section{A. First Year}

Each new faculty member is welcomed to campus the week before classes begin. They participate in new employee orientation programs, and a college of engineering two-day workshop on faculty success. To launch their first day on campus, they begin with breakfast in the college of engineering where they meet the Dean, Dean's Staff, all department heads, and other new faculty hires. At the end of the week, they participate in "Engineering Day" which welcomes our new freshman class into the college. Each new faculty member is partnered with a more experience faculty member as "head honcho" for a fun student activity during orientation. Several social activities during the Fall are intended to welcome not only the faculty member, but also their family, to the area. A welcome back reception is hosted by the Dean of the KGCOE each year, and all new faculty and staff are introduced with a brief story about the individual's personal hobbies and interests. Such introductions often lead to connections with other families in the KGCOE, that help the new hire become comfortable in the new surroundings.

The focus of teaching and educational activities for first year faculty members is on introducing them to the core curriculum. The department head or another senior faculty member in the department accompanies new faculty members to each first class meeting during their first teaching term. The senior faculty member introduces the new faculty member to the class, summarizes the background of the individual, and essentially endorsed the new faculty member as a welcome and valuable addition to the community. This simple act helps to build rapport between the faculty members and the students. First year faculty members are assigned a reduced course load as they get started on their careers, in comparison to the relatively high traditional course load of earlier generations of RIT faculty. The new faculty member will usually be assigned to teach either in the thermal-fluids or solid-body mechanics course sequence. For example, the department usually offers four sections of statics in the fall, four sections of mechanics in the winter, and four sections of dynamics in the spring. Similarly, the department offers multiple sections of thermodynamics in the winter and, of fluid mechanics in the spring, followed by heat transfer the next fall. The new faculty member will teach one section of each course during the year, in close collaboration with other faculty members teaching in the sequence. The senior faculty members share complete course information which goes well beyond the course syllabus, and includes full details of daily lesson plans and lectures. In this process, new faculty learn the culture of engineering education at RIT, and become familiar with learning outcomes assessment and course improvement, while also getting to know at least three colleagues very well. The intent of this close mentoring process is to reduce the traditional startup overhead of course development, while providing a high quality educational experience for the students, and to clearly establish a culture and expectation of collaboration among peer educators. The use of TA's is highly structured in the course sequence, so that the new faculty member does not have to learn how to manage TA's by trial

$14^{\text {th }}$ LACCEI International Multi-Conference for Engineering, Education, and Technology: "Engineering Innovations for 
and error. Managing other people, whether teaching or research assistants, is often a new and frustrating task for junior faculty. This approach demonstrates effective methods for managing the work of others, and for sharing collaborative information. As a new faculty member, they are encouraged to share and learn from detailed course information provided by their peers.

While most new faculty members have significant research experience, many have limited exposure to the writing of proposals or managing grants and contracts. The first year scholarship development program is focused on helping the new faculty member establish a direction for their scholarship program, and building infra-structure for its support. Several workshops and information sessions are held throughout the year by our sponsored programs office. These workshop are presented by senior faculty from around the campus, and by staff members who explain the details of everything from preparing a budget and pre-proposal form, or using NSF FastLane, how to approach a sponsor, and developing white papers about research interests. "Grant-writers Boot Camp”, at the end of the fall quarter, provides a structured setting to aid the faculty member in preparing their first proposal for sponsored research work. Senior ME faculty members are invited to review draft proposals and provide feedback. Recognizing the importance of the short courses, our senior faculty members regularly volunteer to be presenters.

Service expectations of first year faculty members are generally restricted to participation in infrequent department level activities. These include participation in interviews for prospective faculty members, and attending department, college, and institute level faculty meetings. First year faculty members are encouraged to limit their committee participation, and to focus on the other aspects of their career development. This is often a difficult balance for the first year faculty member. Many well-meaning individuals seek out new faculty hires in an effort to engage them in campus life through the wide range of committees and activities in and around the campus. Many first year faculty members feel welcomed by such approaches, and before they realize it, have loaded up their plates with too many activities which draw time away from development of excellence in teaching and establishing their scholarship program. While not part of the formal faculty development program, it is the authors' view that encouraging the first year faculty member to get involved in an off-campus community service activity helps them to "put down roots" and fosters a connection with their entire family. As a result, the author intends to dissuade future first year faculty from oncampus service activities to an even greater extent.

The annual review process at RIT follows a calendar year cycle. By December of their first year, each new faculty member prepares an annual report, using a template provided by the department. The annual report and a written evaluation prepared by the department head lay out a plan for the coming year, and reflect upon the positives and negatives of the first few months on the job. A key element of the first annual review meeting, in January, is to review the KGCOE T\&P guidelines with each new faculty member, and to develop a plan for how they will personally develop their individual career for success. In addition to the formal annual review meeting, the department head makes an effort to meet with each new faculty member at least one time in the Fall, to review any issues surrounding startup, and getting settled in. During that meeting, it is typical to initiate any major purchases that may be anticipated as part of the faculty member's startup package. In the Spring, well after the annual review meeting, another meeting is held to review progress towards proposal submissions, and discuss the development of a "sound bite" or short marketing piece that can be used to describe the role of each faculty member. At this point in time, the faculty member has learned enough about the department that they can begin to see how their unique talents complement the skills of others, and contribute to the strategic directions of the department.

\section{B. Second Year}

The second year teaching development program focuses on two items - quality improvement in delivering the core curriculum, and establishing relationships with a cohort of undergraduate advisees. The second year teaching assignment typically repeats the first year, to reduce course preparation time, and enable the faculty member to think more deeply about pedagogy, while still having a strong support structure. All faculty members in the ME department at RIT are expected to develop a meaningful relationship with their undergraduate advisees. Prior to the beginning of the second academic year, faculty members are invited to a one-day workshop on student advising. The workshop is led by the ME Student Services Coordinator, and includes formal presentations from the department head, various student support services offices around campus (accommodation services, library, co-op, etc.), and lunch with faculty members who had advised freshman students the previous year. After lunch, each faculty member is provided with a briefing packet describing their cohort of advisees, incoming freshman who will be arriving on campus for orientation the following week. Faculty members meet their new advisees on engineering day, and begin the process of developing a life-long relationship with these students, who they will advise throughout their program of study at RIT. The ME student services office works closely with the faculty member throughout the first year, as they learn the curriculum, and how to develop a relationship with students, while not overwhelming their time. The second year faculty member will work with this same group of advisees as they move through the undergraduate program. When the second year faculty member realizes that this advising group represents one of perhaps five or six advising cycles that they will complete over the duration of 
their entire career, they appreciate the wise investment of time in getting to know their students.

The second year scholarship development program consists of several elements. By the end of the first year, or the beginning of the second year, the faculty member will usually have one or two MS (Master of Science, Thesis) students that they have agreed to advise, in addition to any MEng (Master of Engineering, non-thesis) students that may be supporting them in lab development. During the fall quarter, the MS student will develop their thesis proposal in cooperation with the second year faculty member, under the guidance of a full professor in the department, who teaches the Research Methods course. The MS student will then present their proposal to the second year faculty member (their thesis advisor), the Research Methods instructor, the department head, and anticipated thesis committee members. The audience provides feedback not only to the student regarding their thesis proposal, but also off-line to the second year faculty member on tips regarding scope and management of thesis students. As the year progresses, the faculty member begins to receive monthly financial reports from the ME Administrative Services Coordinator on their sponsored projects, and learns how to manage budgets and reporting requirements. During the second year, the faculty member is encouraged to engage one multi-disciplinary capstone design team consisting of six students from multiple engineering departments to create a laboratory experiment, unique item of test equipment, or other infra-structure that will support subsequent research efforts. At the end of the second year, the faculty member will typically take on a full-time co-op student for the summer, so that they are engaging students in all aspects of their scholarship program.

Service expectations of second year faculty members continue to be restricted. One significant departmental committee is assigned, and the second year faculty member serves as a member of the faculty search committee. As a new faculty member they bring a particularly valuable perspective to the search process, and are excellent representatives of the department since they are able to describe first-hand their own experiences with mentoring and career development. By the second year, the faculty member begins service as a technical reviewer for a limited number of conference papers or journal articles. Senior faculty members assist with providing the second year faculty members with appropriate review opportunities.

\section{Third Year}

The third year teaching development program gives the faculty member an opportunity to develop a deliver a new graduate or technical elective course without the detailed structure of the core courses. While this freedom allows the faculty member opportunity to try new things, it also carries a heavier preparation commitment. The faculty member continues to work with their advising cohort, who are now second year students, enrolled in many of the core courses that the faculty member is highly experienced in.

The third year scholarship development program consists of continued progress on research, and how to manage multiple graduate students in the pipeline, at varying degrees of completion. The focus is on expanding the sponsor base for research work and submitting a larger scale, refined proposal such as an NSF Career proposal. During the third year, the faculty member should be able to demonstrate how undergraduate senior design projects, and graduate Master's projects are fully integrated with their scholarship program.

Services activities in the third year include continued service on the faculty search committee, and becoming active in a technical committee of a professional society. Reviewer service on technical papers and proposal review panels is highly encouraged during the year.

The third year is the mid-term review year for the faculty candidate, summarized in Table I. The faculty member meets with the department head at the beginning of the academic year, to thoroughly outline the package of information that will be required for $\mathrm{T} \& \mathrm{P}$ review.

TABLE I

SumMARY OF THE MID-TERM REVIEW PROCESS

\begin{tabular}{|l|l|}
\hline Date & $\begin{array}{l}\text { Item } \\
\text { Items in italics are specific to the ME Dept. . }\end{array}$ \\
\hline Dec & Candidate submits documentation for review. \\
\hline Jan & Mid-term seminar to ME Faculty \\
\hline Mar & Faculty peer reviews due to Dept. . Head \\
\hline Apr & $\begin{array}{l}\text { Mid-term seminar to Program Advisory Committee } \\
\text { PAC reviews due to Dept. . Head } \\
\text { External reviews due to Dept. . Head }\end{array}$ \\
\hline May & Mid-Term review meeting with Dept. . Head \\
\hline June & Mid-Term review meeting with Dean \\
\hline
\end{tabular}

The faculty candidate assembles documentation including self-assessment of educational activities, scholarly activities, and service activities, copies of annual reports and reviews, student evaluations, publications, appointment letters, abstracts of sponsored grants and contracts, and work load history for the first three years of the appointment. The faculty candidate is invited to present a faculty seminar during a regular faculty meeting. The seminar is not intended to be a traditional research seminar, but rather is supposed to provide the candidate with an opportunity to summarize their past accomplishments and future plans for career development from a holistic perspective. All faculty members are expected to attend this presentation (including those in their first and second years of appointment), which typically lasts 30 minutes, and actively participate in the 20-minute question and answer session which follows. This presentation, and the presentation that the candidate made when they originally interviewed for the position, are both posted on the secure web site. Each tenured faculty member is charged with preparing a one-page feedback evaluation form which addresses the same elements included on the candidate's annual review evaluation. The department head prepares his own assessment, and appends all input from all tenured faculty members as part of

$14^{\text {th }}$ LACCEI International Multi-Conference for Engineering, Education, and Technology: "Engineering Innovations for 
the candidate's mid-term review assessment. The head then meets with the candidate to discuss the results of the assessment, and develop an action plan going forward.

Typically, the mid-term review will identify areas of strength that the candidate may build upon. The feedback may help the faculty member adjust their plans, and develop a means to address areas of concern that may have been identified. Should it become clear that the faculty member is not making acceptable progress towards tenure at any point after two full years of service, the department head may notify the faculty member by the end of June that they will be granted a terminal contract for one additional year. The conclusion of the third year, even for highly successful junior faculty members, tends to be a time of significant reflection about the future direction of their career. By this time, most faculty members have an accurate understanding of how they are progressing towards tenure, and are in a good position to begin thinking strategically about the long-term.

\section{Fourth Year}

The fourth year teaching development program expands the faculty member's base in the curriculum. If the faculty member offered a technical elective in the third year, they will typically be asked to offer a graduate course in the fourth year, or vice-versa. The loading of core courses is adjusted to reflect the scale of the faculty member's scholarship program relative to other faculty. The undergraduate advisee cohort is now composed of third year students beginning their co-op experiences. An advisor training program helps faculty members understand the upper division curriculum and degree requirements, and how to advise students as they make decisions about career options and professional development.

The fourth year scholarship development program focuses on helping the faculty member expanding their success in research. At this point, faculty members usually begin to feel over-whelmed with managing multiple contracts and handling personnel issues with graduate students. The department head and office staff mentor the fourth year faculty member to become an effective program manager.

Service contributions are expected to grow in the fourth year. The faculty member is encouraged to take a position as vice-chair of a professional society conference session, continue service as a technical reviewer, and engage with the local section of a professional society. Faculty members are often approached by student groups to become a club advisor.

\section{E. Fifth Year}

The fifth year teaching development program focuses on quality improvement. No new courses are typically expected, and the faculty member has a course load that should be familiar. Their advisee cohort continues to be on-campus and off-campus as they rotate through co-op assignments.

The faculty member's research program should be selfsustaining, and able to stand on its own. Additional investments are generally focused on growth of the scholarship program, as opposed to subsidizing the scholarship program. The faculty member should be able to demonstrate a regular flow of publications and graduate students, and constantly be recruiting new students and writing new proposals to back-fill projects and students coming to completion.

Service contributions in the fifth year may include membership on a college or university-level committee, and continued membership in the local professional society. At the national level, the faculty member is encouraged to serve as a session chair for a professional society meeting.

\section{F. Sixth Year}

The sixth year requires continued excellence in teaching, advising, research, and service. The faculty member's first cohort of advisees will graduate this year, and they may be assigned a second group of incoming freshmen. Success in the faculty member's scholarship program should be evidenced through external citations to their work, and external reviewers, many of whom they know through prior professional society affiliations, should be in a position to comment on the progress of the faculty members. The faculty member will typically continue service on the college or university level committee they had been assigned to during the preceding year.

The candidate submits their complete T\&P packet by September of the evaluation year. The evaluation consists of reviews conducted at the departmental and college level, with the final decisions regarding T\&P made by the Provost. The T\&P review process [41] is summarized in Table II.

TABLE II

SUMMARY OF THE REVIEW PROCESS FOR TENURE AND PROMOTION [41].

\begin{tabular}{|l|l|}
\hline $\begin{array}{l}\text { Due } \\
\text { Date }\end{array}$ & $\begin{array}{l}\text { Item } \\
\text { Items in italics are specific to the ME Dept. }\end{array}$ \\
\hline 15 Sep & Candidate submits documentation for review. \\
\hline 15 Oct & $\begin{array}{l}\text { Department Head notifies Dean of Candidates to be reviewed, } \\
\text { and solicits external reviews of candidate's portfolio. }\end{array}$ \\
\hline 1 Nov & $\begin{array}{l}\text { Senior ME Faculty meet in Deliberation and cast written } \\
\text { votes, with individual letters. }\end{array}$ \\
\hline 15 Nov & $\begin{array}{l}\text { Department Head submits the outcome of the Departmental } \\
\text { Committee assessment to Dean and the College Tenure } \\
\text { Committee. }\end{array}$ \\
\hline 15 Nov & Department Head submits personal recommendation to Dean. \\
\hline 15 Jan & $\begin{array}{l}\text { College Tenure Committee completes review process and votes } \\
\text { on a tenure recommendation. }\end{array}$ \\
\hline 1 Feb & $\begin{array}{l}\text { College Tenure Committee Chair submits summary of } \\
\text { committee deliberations to Dean and Provost. }\end{array}$ \\
\hline 8 Feb & Dean submits personal recommendation to Provost. \\
\hline 1 Mar & Provost informs candidate of the final decision. \\
\hline
\end{tabular}

In March, the faculty member is notified of the Provost's decision. The candidate's promotion as a tenured associate professor, effective with the beginning of the next academic year, is announced. In the event a faculty member is not granted tenure, a terminal appointment is made, and the department head works with the candidate on a transition plan.

Digital Object Identifier:.

14 ${ }^{\text {th }}$ LACCEI International Multi-Conference for Engineering, Education, and Technology: "Engineering Innovations for Global Sustainability”, 20-22 July 2016, San José, Costa Rica. 
The department does not hire faculty members with the intention denying tenure.

\section{F. Summary}

The typical teaching, research, and service program development and the corresponding review processes are summarized in Table III.

TABLE III

PROGRESSION OF A TYPICAL ASSISTANT PROFESSOR ON THE PATH TOWARDS TENURE AND PROMOTION.

\begin{tabular}{|c|c|c|c|c|}
\hline Yr. & Teaching & Research & Service & Reviews \\
\hline 1 & $\begin{array}{l}\text { Core Courses: } \\
\text { e.g. thermo, } \\
\text { fluids, heat } \\
\text { Observe how to } \\
\text { Manage a TA }\end{array}$ & $\begin{array}{l}\text { Present Graduate } \\
\text { Seminar, publish } \\
\text { prior work, } \\
\text { develop Lab, } \\
\text { Manage one grad. } \\
\text { student, Grant } \\
\text { Writer’s Boot } \\
\text { Camp, New PI } \\
\text { proposals }\end{array}$ & $\begin{array}{l}\text { Minimal } \\
\text { Expectations, } \\
\text { Participate in } \\
\text { departmental } \\
\text { social events. } \\
\text { Engage in } \\
\text { campus and } \\
\text { community } \\
\text { activities }\end{array}$ & $\begin{array}{l}\text { Attend Faculty } \\
\text { Seminars } \\
\text { Annual } \\
\text { Review with } \\
\text { Dept. Head }\end{array}$ \\
\hline 2 & $\begin{array}{l}\text { Core Courses; } \\
\text { Advisor training } \\
1^{\text {st }} \text { Year } \\
\text { Advisees } \\
\text { Engage Sr. } \\
\text { Design Projects }\end{array}$ & $\begin{array}{l}\text { Submit new-work } \\
\text { Publications } \\
\text { Manage MS RA, } \\
\text { co-op, Learn } \\
\text { Budget Mgm't., } \\
\text { Renewal Proposals } \\
\text { First CAREER } \\
\text { Proposal }\end{array}$ & $\begin{array}{l}\text { Faculty Search } \\
\text { Committee } \\
\text { Member } \\
\text { Technical Paper } \\
\text { Reviewer }\end{array}$ & $\begin{array}{l}\text { Attend Faculty } \\
\text { Seminars } \\
\text { Annual } \\
\text { Review with } \\
\text { Dept. Head } \\
\text { End of year } \\
\text { Meeting with } \\
\text { Dean }\end{array}$ \\
\hline 3 & $\begin{array}{l}\text { Core Courses; } \\
\text { Graduate Course } \\
\text { Offering; 2nd } \\
\text { Year Advisees, } \\
\text { Integrate Sr. } \\
\text { Design Projects } \\
\text { w/ Scholarship } \\
\text { program }\end{array}$ & $\begin{array}{l}\text { Continue progress } \\
\text { on Research \& } \\
\text { Scholarship } \\
\text { Multiple MS } \\
\text { Students, RAs, co- } \\
\text { ops, Expand } \\
\text { sponsor base, } \\
\text { Second CAREER } \\
\text { Proposal } \\
\end{array}$ & $\begin{array}{l}\text { Faculty Search } \\
\text { Committee, } \\
\text { Prof. Society } \\
\text { Committee } \\
\text { Member, } \\
\text { Technical Paper } \\
\text { Reviewer, } \\
\text { Proposal } \\
\text { Review Panel }\end{array}$ & $\begin{array}{l}\text { Faculty } \\
\text { Seminar, } \\
\text { Mid-Term } \\
\text { review by Sr. } \\
\text { faculty and } \\
\text { Dept. Head, } \\
\text { Mid-Term } \\
\text { review with } \\
\text { Dean } \\
\end{array}$ \\
\hline 4 & $\begin{array}{l}\text { Core Courses; } \\
\text { Tech. Elective; } \\
\text { Advisor } \\
\text { Training, 3rd } \\
\text { Year Advisees }\end{array}$ & $\begin{array}{l}\text { Sustained } \\
\text { progress on } \\
\text { research and } \\
\text { scholarship }\end{array}$ & $\begin{array}{l}\text { Conf. Session } \\
\text { Vice-chair; } \\
\text { Reviewer; } \\
\text { Professional } \\
\text { Society }\end{array}$ & $\begin{array}{l}\text { Annual } \\
\text { Review with } \\
\text { Dept. Head }\end{array}$ \\
\hline 5 & $\begin{array}{l}\text { Core, technical } \\
\text { elective, or } \\
\text { graduate } \\
\text { courses; } \\
4^{\text {th }} \text { Year } \\
\text { Advisees }\end{array}$ & $\begin{array}{l}\text { Sponsored } \\
\text { research program } \\
\text { should be self- } \\
\text { sustaining. } \\
\text { Regular flow of } \\
\text { publications and } \\
\text { graduate students } \\
\text { established. }\end{array}$ & $\begin{array}{l}\text { Conference } \\
\text { Session Chair; } \\
\text { Professional } \\
\text { Society; } \\
\text { College or } \\
\text { University } \\
\text { committee }\end{array}$ & $\begin{array}{l}\text { Annual } \\
\text { Review with } \\
\text { Dept. Head }\end{array}$ \\
\hline 6 & $\begin{array}{l}\text { First Advising } \\
\text { Class } \\
\text { graduates, } \\
\text { Second group } \\
\text { of Advisees }\end{array}$ & $\begin{array}{l}\text { External citations } \\
\text { should provide } \\
\text { evidence of } \\
\text { impact } \\
\text { External } \\
\text { reviewers }\end{array}$ & $\begin{array}{l}\text { Continue } \\
\text { Professional, } \\
\text { College, and } \\
\text { Institute } \\
\text { service. }\end{array}$ & $\begin{array}{l}\text { P \& T } \\
\text { Review, } \\
\text { meet with } \\
\text { Dept. Head } \\
\text { \& Dean }\end{array}$ \\
\hline
\end{tabular}

\section{CASE STUDY DESCRIPTION}

Two cohorts of faculty were compared in this case study. The ME department at RIT hired ten tenure-track assistant professors into the department during one decade. Four assistant professors were hired before the CDP was developed and therefore did not participate in the program, while six were hired after the CDP was in place and did participate. The effectiveness of the CDP was evaluated by comparing these two cohorts. Four attributes were compared: (1) Teaching Effectiveness, (2) Scholarship, (3) Service and (4) faculty selfassessment of their understanding of T\&P expectations.

\section{RESULTS}

The cohort of assistant professors who participated in the career development program are referred to as "With CDP" in the following results. The cohort of assistant professors who did not participate in the career development program, are referred to as "Without CDP" in the following results.

\section{A. Teaching Effectiveness}

Every academic quarter, the ME department conducts student evaluation of teaching effectiveness of every faculty member teaching lecture courses in the department. The student survey instrument provides students with an opportunity to provide feedback on seventeen aspects of the course, the text, and the instructor's performance. Eight specific questions are asked regarding the instructor's performance on items such as return of graded work, availability, communication skills, and course classroom management. One question invites the students to rate the "overall instructor performance" of the faculty member. The data presented here summarizes the average value of the "overall instructor performance" for all instructors with and without participation in the career development program. Data is collected during fall, winter, and spring of each year. The results are illustrated in Figure 1. The horizontal axis represents the sequential term following hire for each faculty member, and the vertical axis represents the mean of the student response for the faculty cohort. The student survey results in this data reflect similar course assignments for the various faculty members. The vertical axis is a numerical representation of a Likert scale, with a value of 1 representing "Unsatisfactory" and a value of 5 representing "Outstanding." Six full years of data are available for the faculty members without the career development program, while a maximum of four years are available for those participating in the career development program, reflecting the relatively recent introduction of the career development program. The number of faculty members included in each average is variable, since faculty members are at different points in their progress towards promotion and tenure. While a finer level of detail is available for the data, it is not presented here in the interest of individual privacy. The mean value of "Overall Instructor Performance” for all ME faculty members (adjuncts, tenured, tenure-track, instructors) for all academic quarters during the evaluation period was 4.11, shown as the dashed line in Fig. 1.

$14^{\text {th }}$ LACCEI International Multi-Conference for Engineering, Education, and Technology: "Engineering Innovations for 


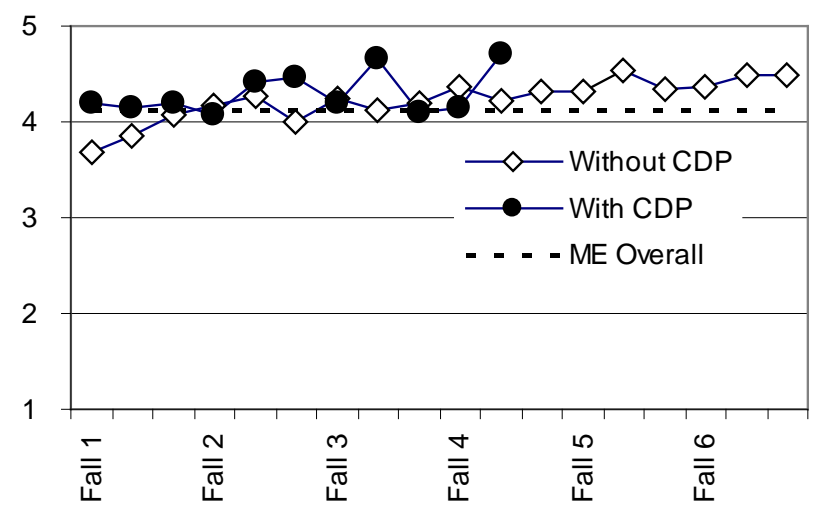

Fig. 1 Average student evaluation of "Overall Instructor Performance" as a function of academic quarter following initial hire for tenure-track assistant professors.

Faculty members in the Career Development Program consistently demonstrated student satisfaction that was significantly better than or comparable to faculty members not engaged in the Career Development Program. Furthermore, faculty members in the Career Development Program consistently demonstrated student satisfaction that was significantly better than or comparable to the average performance of the entire ME faculty. The cohort of faculty members in the Career Development Program demonstrated student satisfaction at the departmental average during their first year of hire, while the cohort of faculty members not in the career development program tended to be lower than the departmental average.

Student perception of "Instructor is Stimulating” earned the lowest score, with a mean value of 3.77 for all ME faculty members (adjuncts, tenured, tenure-track, instructors) for all academic quarters during the evaluation period. The mean values for the ME department and both faculty cohorts are shown as a function of academic quarter in Figure 2.

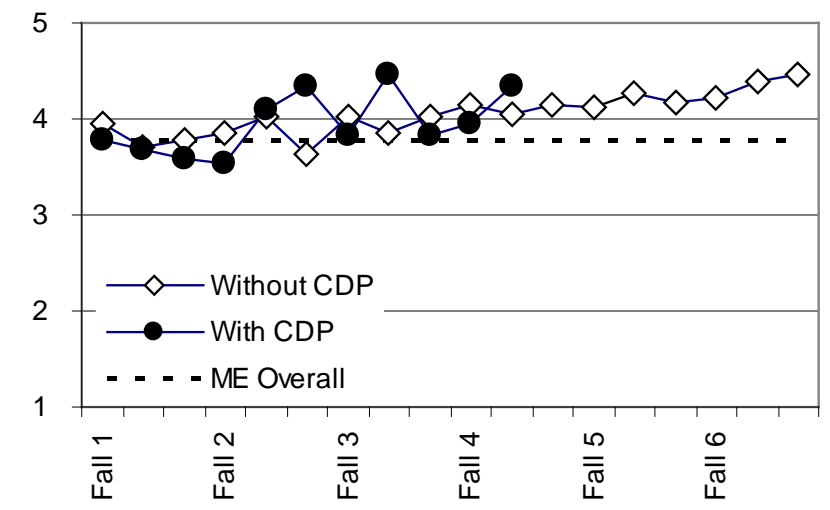

Fig. 2 Average student evaluation of "Instructor is Stimulating" as a function of academic quarter following initial hire for tenure-track assistant professors.

The results of Figure 2 suggest that faculty members without the CDP show steady improvement over time. The faculty with the CDP appear to exhibit somewhat greater volatility in ratings for the attribute "Instructor is Stimulating."
Junior faculty members appear to be consistently above the departmental average by year three and later.

\section{B. Scholarship}

Faculty members submit annual reports, which include a listing of all journal publications, conference publications, and other works appearing during the preceding year. The average number of journal publications appearing per year per person are illustrated for both cohorts in Figure 3. The average number of journal publications per year per person is higher for the cohort of faculty participating in the career development program, than for the cohort not participating.

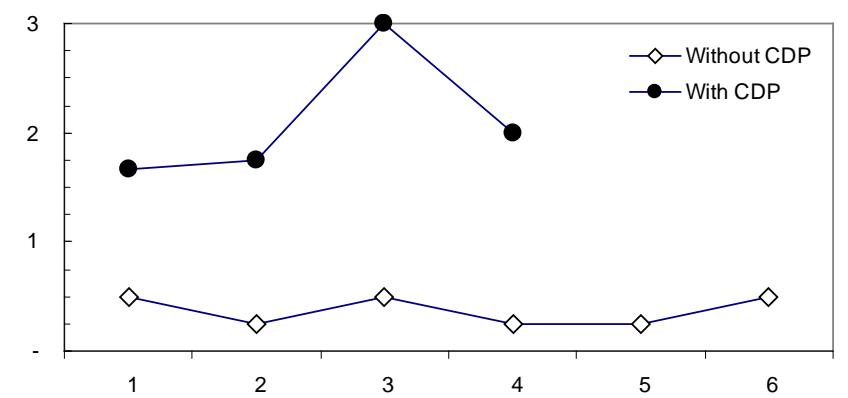

Fig. 3 Average number of journal publications per person as a function of academic year following initial hire for tenure-track assistant professors.

The average number of conference publications appearing per year per person are illustrated for both cohorts in Figure 4. The conference publication activity is higher for the cohort of faculty participating in the career development program, than for the cohort not participating.

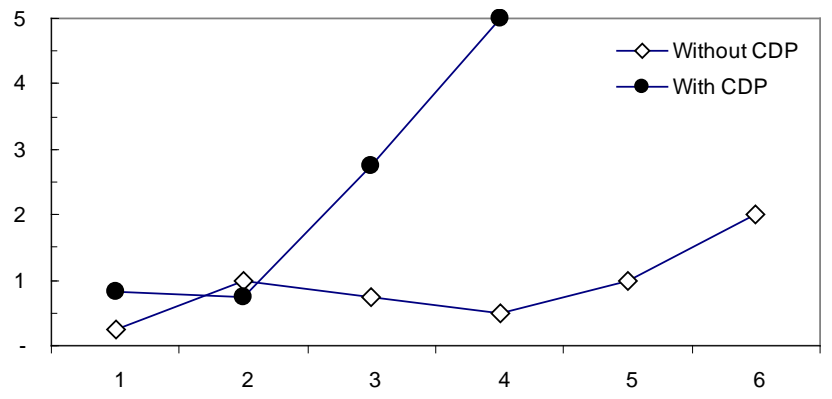

Fig. 4 Average number of conference publications per person as a function of academic year following initial hire for tenure-track assistant professors.

The institution maintains an active database of all proposals submitted to external agencies, and tracks participation by individual, department, and several other categories such as funding agency. The date of proposal submission, and the date of contract award are recorded in this database, and provide a convenient source of data for comparing the scholarship performance of the faculty cohorts considered herein. The average number of external proposals submitted per year per person are illustrated for both cohorts in Figure 5. The average number of external proposals submitted per year per person is higher for the cohort of 
faculty participating in the career development program, than for the cohort not participating. The cohort of faculty members participating in the career development program began submitting proposals earlier in their career.

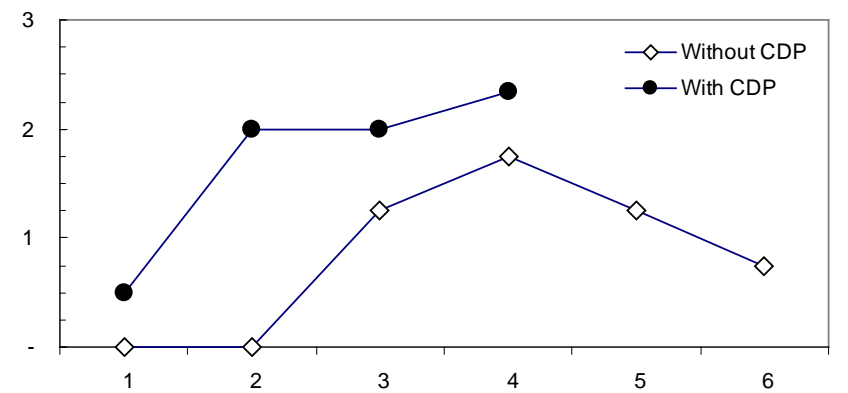

Fig. 5 Average number of external proposals submitted per person as a function of calendar year following initial hire for tenure-track assistant professors.

The average number of external grants and contracts received (as a result of the proposals previously submitted) per year per person are illustrated for both cohorts in Figure 6. The average number of external awards per year per person is higher for the cohort of faculty participating in the career development program, than for the cohort not participating. The cohort of faculty members participating in the career development program began earning awards earlier in their career at a higher success rate than the cohort of faculty not participating in the career development program.

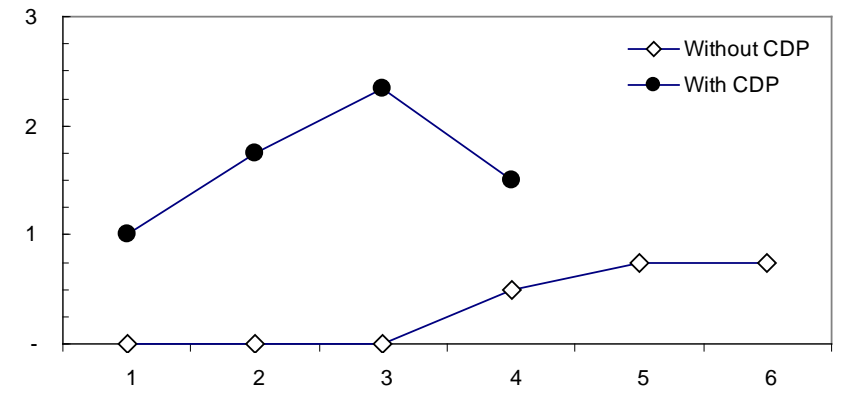

Fig. 6 Average number of external grant and contract awards per person as a function of calendar year following initial hire for tenure-track assistant

\section{Service} professors.

Faculty members are encouraged to participate in offcampus professional service activities such as local and national professional society membership, national committee services, technical paper and proposal peer reviewing, and similar activities related to their career development. Faculty members may also have on-campus service duties such as departmental, college, and university level service. Both offcampus and on-campus service activities are included in the faculty member's annual report. At the conclusion of the annual report, faculty members are also invited to list their local community involvement, and participation in organizations such as clubs, community organizations, school activities, outreach programs, and similar activities.
Community involvement activity reporting is not required, nor used as performance evaluation criteria, but can provide insight regarding whether the faculty member is feeling connected to the community, which in turn might reflect their perception of quality of life, and subsequently retention.

Participation in off-campus professional society and service organization activities are illustrated for both cohorts in Figure 7. The average number of off-campus service activities reported per year per person is higher for the cohort of faculty participating in the career development program, than for the cohort not participating.

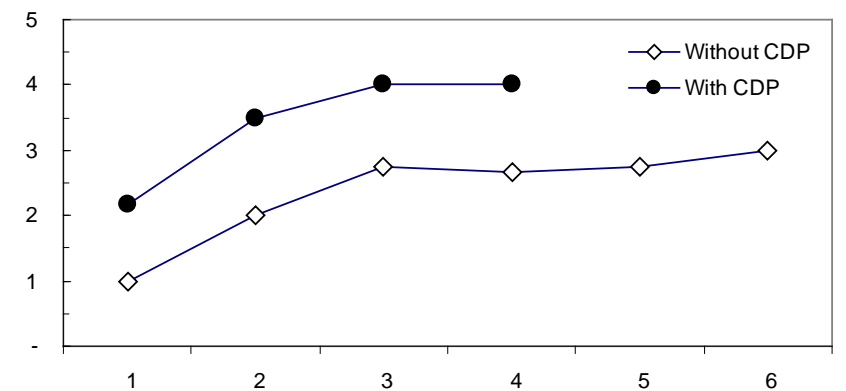

Fig. 7 Average number of off-campus professional service organizations per person per year as a function of calendar year following initial hire for tenure-track assistant professors.

Participation in on-campus service activities are illustrated for both cohorts in Figure 8. The average number of oncampus service activities reported per year per person starts out higher for the cohort of faculty participating in the career development program and appears to approach the long-term value for the cohort not participating.

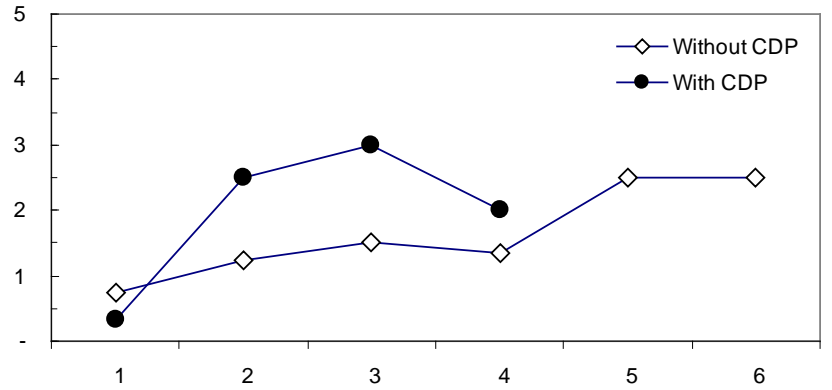

Fig. 8 Average number of on-campus service activities per person per year as a function of calendar year following initial hire for tenure-track assistant professors.

The average number of community involvement activities per year per person are illustrated for both cohorts in Figure 9. The average number of community involvement activities reported per year per person starts out higher for the cohort of faculty participating in the career development program and appears to approach the long-term value for the cohort not participating.

14 ${ }^{\text {th }}$ LACCEI International Multi-Conference for Engineering, Education, and Technology: "Engineering Innovations for 


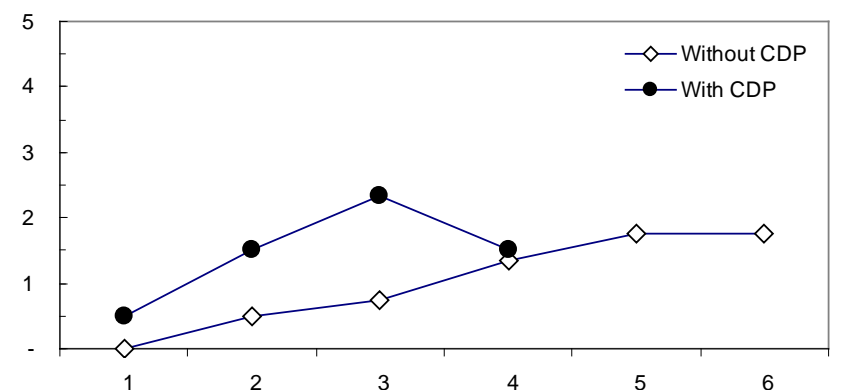

Fig. 9 Average number of community involvement activities per person as a function of calendar year following initial hire for tenure-track assistant professors.

\section{Faculty Perception Survey}

The ten faculty members were invited to anonymously complete a short survey of ten attributes. Nine individuals responded to the request. The cohort "Without CDP" had completed the entire promotion and tenure process, while the cohort "With CDP" remain on the path towards promotion and tenure. The respondents were instructed to "Please respond to each item below, from the perspective of a PRE-TENURE faculty member, describing your experience and perceptions from the date of hire through the tenure-review process" and evaluate ten attributes on a Likert scale from 1 to 5 , with a value of 1 indicating "Strongly Disagree", a value of 3 indicating "Undecided", and a value of 5 indicating "Strongly Agree.” The ten statements included on the survey were:

I understand the expectations regarding ...

- classroom teaching effectiveness as they relate to my T\&P,

- undergraduate student advising effectiveness as they relate to my T\&P,

- graduate student advising effectiveness as they relate to my $\mathrm{T} \& \mathrm{P}$,

- scholarship effectiveness as they relate to my T\&P,

- archival (such as journal) publication as they relate to my T\&P,

- non-archival (such as conference) publication as they relate to my T\&P ,

- external sponsored program proposal writing efforts as they relate to my T\&P ,

- professional (off-campus) service as they relate to my T\&P,

- academic (on-campus) service as they relate to my T\&P, and

- I have become engaged in my community (off campus) and feel "connected" to the Rochester area.

Each respondent was asked whether they first began their tenure track appointment in Fall 2002 or earlier (Without CDP), or in Fall 2003 or later (With CDP). The average responses for both cohorts are illustrated in Figure 10. The cohorts show close agreement regarding the expectations of teaching effectiveness, undergraduate advising, and academic service. The cohort of faculty members participating in the career development program expressed a clearer understanding of the remaining six attributes than did the cohort not participating in the career development program. The participating cohort also indicated a somewhat higher sense of "connection" to the local community.

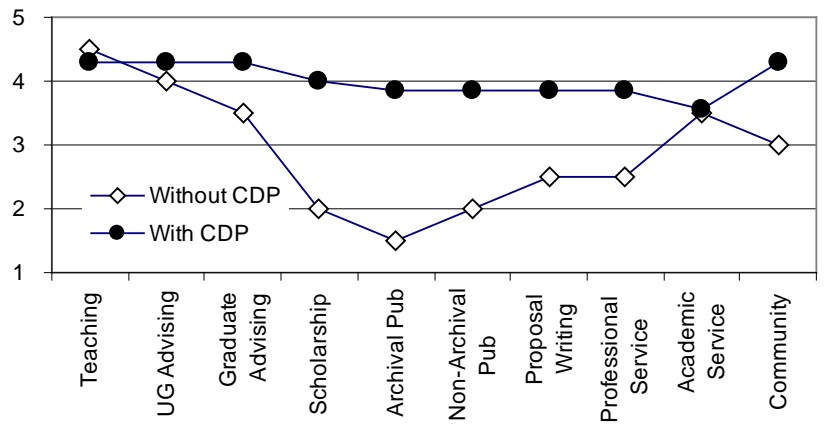

Fig. 10 Tenure-track assistant professor survey responses for various attributes $(\mathrm{N}=9)$.

\section{CONCLUSIONS}

A Career Development Program (CDP) for tenure track assistant professors can contribute to improving many aspects of early career performance. Faculty members participating in the CDP demonstrated superior mean performance on almost every quantifiable measure of scholarship performance, such as archival and non-archival publication, proposal submission, and external awards. Faculty members in the CDP demonstrated earlier participation in professional service (offcampus), academic service (on-campus), and community involvement activities. Average student perception of the faculty member's performance for those faculty members in the CDP cohort was comparable to or better than the cohort of faculty members not participating. Tenure-track faculty members participating in the CDP expressed significantly better understanding of the performance expectations for junior faculty in six of nine categories, and comparable understanding in three categories. Faculty members in the CDP appear to be connected to the local community earlier and more successfully based on self-perception and their participation in community activities.

\section{REFERENCES}

[1] Issen, K.A., Kinsey, B., Brinson, L.C., Broadbelt, L.J., "Preparing future engineering faculty: A professional development series", Proceedings of the 2001 ASEE Annual Conference and Exposition, p 7973-7985, 2001.

[2] Dziedzic, M., Janissek, P.R., Tozzi, M.J., “A graduate course in faculty development", Proceedings of the 37th ASEE/IEEE Frontiers in Education Conference, FIE, p T1J14-T1J17, 2007.

[3] Harrow, K., "Faculty Development Program", SIGCSE Bulletin (Association for Computing Machinery, Special Interest Group on Computer Science E), v 14, p 170-173, Feb 1982.

[4] Litchfield, Bruce, "Faculty development: the teaching college", Proceedings of the 1999 Frontiers in Education Conference, v 3, p 13d4-13, 1999.

[5] Bigio, D., Schmidt, J.,"Workshop for faculty development based on the underlying pedagogical issues of ABET EC 2000", Proceedings of the 1999 Frontiers in Education Conference, v 1, p 12a1-5 - 12a1-9, 1999.

[6] Marra, R. M., Litzinger, T. A, "Learning to juggle: A model for new engineering faculty development”, Proceedings of the 2000 ASEE Annual Conference and Exposition, pp 4039-4050, 2000.

Digital Object Identifier: (to be inserted by LACCEI).

$14^{\text {th }}$ LACCEI International Multi-Conference for Engineering, Education, and Technology: "Engineering Innovations for 
[7] Brawner, C., Felder, Richard M., Allen, Rodney, Brent, Rebecca “A survey of faculty teaching practices and involvement in faculty development activities”, Journal of Engineering Education, v 91, n 4, p 393-396, October 2002.

[8] Fahrenholtz, W.G., Bieniek, R. J., Graham, S.W. “Multi-campus new faculty development to improve the culture of teaching”, Proceedings of the 2003 ASEE Annual Conference and Exposition, p 7525-7533, 2003.

[9] Schulz, N., Schulz, K., "Faculty development - The future of engineering education”, Proceedings of the ASEE 2004 Annual Conference and Exposition, p 5649-5656, 2004.

[10] Froyd, J., Fowler, D., Layne, J., Simpson, N., "Frameworks for faculty development", Proceedings of the 35th Annual Frontiers in Education Conference: Pedagogies and Technologies for the Emerging Global Economy, FIE'05, p S3E-23-S3E-28, 2005.

[11] McShannon, J., Hynes, P., Nirmalakhandan, N., Venkataramana, G., Ricketts, C., Ulery, A., Steiner, R. "Gaining retention and achievement for students program: A faculty development program”, Journal of Professional Issues in Engineering Education and Practice, v 132, n 3, p 204-208, July 2006.

[12] Elger, D., Metlen, S., Carson, R., Utschig, T., Cordon, D., Racine, M., Beyerlein, S., "A case study to explore learning during a faculty development workshop”, Proceedings of the 2006 ASEE Annual Conference and Exposition.

[13] Froyd, J., Layne, J., Fowler, D., Simpson, N., "Design patterns for faculty development", Proceedings of the 37th ASEE/IEEE Frontiers in Education Conference, p T1J1-T1J5, 2007.

[14] Solti, J., Greer, J., Waters, P., “Getting from here to there: A selfdiagnostic for stimulating faculty development”, Proceedings of the 1999 ASEE Annual Conference and Exposition, p 2497-2507, 1999.

[15] Layne, J., Froyd, J., Morgan, J., Kenimer, “Faculty learning communities”, Proceedings of the 2002 Frontiers in Education Conference, v 2, FIA p 13-18, 2002.

[16] Jugdev, K., “Advice for new engineering faculty: Insights gained from faculty development programs”, Proceedings of the 2007 ASEE Annual Conference and Exposition, 2007.

[17] Jones, E.B., Martinez, D., "Meeting the mentoring needs of new faculty: An interdisciplinary experience”, Proceedings of the 2008 ASEE Annual Conference and Exposition, 2008.

[18] Buchanan, W. W., "Expectations for faculty development in engineering technology”, Proceedings of the 1997 ASEE Annual Conference, 1997.

[19] Fulton, C., Licklider, B.L., "Re-engineering faculty development: lessons learned.”, Proceedings of the 1998 ASEE Annual Conference, 9 pp, 1998.

[20] Reese, D., Schulz, K., Schulz, N., King, R., “A third year review of the faculty development program at Mississippi State University”, Proceedings of the 2006 ASEE Annual Conference and Exposition, 2006

[21] "Developing Metrics for Assessing Engineering Instruction: What Gets Measured is What Gets Improved”, Report from the Steering Committee for Evaluating Instructional Scholarship in Engineering; National Academy of Engineering. http://www.nap.edu/catalog/12636.html ISBN: 0-309-13783-7, 52 pages, 2009.

[22] Felder, Richard M., "Faculty development: getting the sermon beyond the choir”, Proceedings of the 1998 ASEE Annual Conference, 7pp, 1998.

[23] Mourtos, N.J., Allen, E. L., “Assessing the effectiveness of a faculty development program”, Proceedings of the 1999 Frontiers in Education Conference, v 3, p 135-8, 1999.

[24] Sanders, K., Carlson-Dakes, C., Mitchell, J., Farrell, P., "Faculty development workshops on the road: What's missing?” Proceedings of the 2000 ASEE Annual Conference and Exposition, pp. 2747-2759, 2000.

[25] Brent, Rebecca, Felder, Richard, Regan, Thomas, Walser, Ardie, Carlson-Dakes, Chris, Evans, Donald, Malave, Cesar, Sanders, Katherine, McGourty, Jack, "Engineering faculty development: A multicoalition perspective', Proceedings of the 2000 ASEE Annual Conference and Exposition, p 2479-2489, 2000.
[26] Varma, V.K., Varma, T., "Important steps to skillful mentoring of new faculty: Avoiding the pitfalls", Proceedings of the 2001 ASEE Annual Conference and Exposition, p 5647-5652, 2001.

[27] Brawner, C.E.; Felder, R.M.; Allen, R.H.; Brent, R., “The impact of faculty development activities on engineering faculty teaching practices”, Proceedings of the 2001 ASEE Annual Conference and Exposition, pp 10191-10201, 2001.

[28] Layne, J., Froyd, J., Simpson, N., Caso, R., Merton, P., “Understanding and improving faculty professional development in teaching", Proceedings of the 34th ASEE/IEEE Frontiers in Education Conference: Expanding Educational Opportunities Through Partnerships and Distance Learning, V 3, p S1C-15-S1C-20, 2004.

[29] Wong, Ernest, Wolter, Jason, Trainor, Timothy, "Work in progress: College faculty development - Systems engineering and the West Point way”, Proceedings of the 36th ASEE/IEEE Frontiers in Education Conference, FIE, 2006.

[30] Utschig, T.T., Schaefer, D., "Opportunities and challenges in professional education-related faculty development in the US”, Proceedings of the 38th ASEE/IEEE Frontiers in Education Conference, FIE 2008, p S4D17-S4D22, 2008.

[31] Ketchum Jr., L.H., “Civil Engineering Faculty Development”, ASCE Eng Issues J Prof Act, v 104, n 2, p 115-119, Apr 1978.

[32] Pocock, J.B., Kuennen, S.T., "Developing civil engineering faculty”, Proceedings of the 2003 ASEE Annual Conference and Exposition, $p$ 2759-2766, 2003.

[33] Nixon, W., "A survey of faculty development activities in civil engineering”, Proceedings of the 2007 ASEE Annual Conference and Exposition, 2007.

[34] Faseyitan, S., "Faculty development on information technology: some issues to consider”, Proceedings of the 1994 Frontiers in Education Conference, p 620-623, 1994.

[35] Yurtseven, H. O., "Effective use of development plan for promotion and tenure of engineering technology faculty”, Proceedings of the 2002 ASEE Annual Conference and Exposition: Vive L'ingenieur, p 76937699, 2002.

[36] Suchan, W. K., Blair, Jean R. S., Fairfax, D., Goda, B.S.; Huggins, K.L., Lemanski, M.J., "Faculty development in information technology education”, Proceedings of the 7th ACM SIG-Information Technology Education Conference, SIGITE 2006, v 2006, p 15-18, 2006.

[37] Terry, Ronald E., Sandholtz, K., "Non-traditional faculty development program”, Proceedings of the 1999 Frontiers in Education Conference, v 3, p 134-136, 1999.

[38] McNutt, A.S., "Faculty Development in Two-year Colleges", Proceedings of the 1984 ASEE Annual Conference, v 2, p 745-748, 1984.

[39] McNutt, A., "Unrivaled Challenge: Faculty Development in the two-year College”, Proceedings of the 1998 ASEE Annual Conference, v 2, p 1025-1027, 1985.

[40] Rochester Institute of Technology, Institute Policy and Procedures Manual. Section E5.0 Policies on Tenure, revised May 2009.

[41] Kate Gleason College of Engineering, Rochester Institute of Technology, Tenure Policy \& Procedures, January 2006.

$14^{\text {th }}$ LACCEI International Multi-Conference for Engineering, Education, and Technology: "Engineering Innovations for 